\title{
Fairtrade Towns as Unconventional Networks of Ethical Activism
}

\author{
Ken Peattie $^{1}$ (D) Anthony Samuel ${ }^{1}$
}

Received: 21 June 2016/ Accepted: 15 November 2016/Published online: 8 December 2016

(C) The Author(s) 2016. This article is published with open access at Springerlink.com

\begin{abstract}
The growing availability and consumption of Fairtrade products is recognised as one of the most widespread ethically inspired market developments, and as an example of activist-driven change within the wider marketing system. The Fairtrade Towns movement, now operating in over 1700 towns and cities globally, represents a comparatively recent extension of Fairtrade marketing driven by local activists seeking to promote positive change in production and consumption systems. This paper briefly explores the conventional framing of the role that ethically related activism plays in the operation of markets and in influencing market participants. It then presents key insights gathered from a grounded theory exploration of Fairtrade Towns as activist-driven marketing systems, revealing the atypical nature of the activism involved. The findings demonstrate how local activists leverage their social networks to exert pressure and generate support to promote ethical consumption. The study suggests that Fairtrade Towns offer a new role for activists as Fairtrade itself becomes more mainstream, and considers the role they are fulfilling as 'informal' local marketers. The marketing dynamics revealed represent a complex and distinctive form of relational activism that seeks to build Fairtrade markets and highlight their positive benefits, with potential lessons for other local ethical market-building efforts in future.
\end{abstract}

Ken Peattie

Peattie@cf.ac.uk

Anthony Samuel

SamuelA3@cf.ac.uk

1 Cardiff Business School, 33 Park Place, Cardiff CF10 3BA, UK
Keywords Fairtrade - Activism - Localism · Market development · Grounded theory

\section{Introduction}

Fair Trade (FT) represents one of the most significant contexts for research into the development of ethical markets, and our growing understanding of FT owes much to the key contributions within Journal of Business Ethics. These contributions help us to understand the development of the FT movement and the challenges it faces (Child 2015; Hira and Ferrie 2006; Jaffee 2010; Moore 2004; Nicholls 2010), and the ethical dimensions of the decisions and actions of FT suppliers (Davies and Crane 2003; Davies and Ryals 2010), FT consumers (Castaldo et al. 2009; Chatzidakis et al. 2007, 2016; De Pelsmacker and Janssens 2007; Doran 2009; Doran and Natale 2011; Kim et al. 2010) and the supply networks that connect them (Davies 2009; Davies et al. 2010).

A significant development in FT markets and marketing, which is comparatively both recent and under-researched, is the Fairtrade Towns (FTT) movement. This began in 2001 when a group of local activists within the small town of Garstang UK persuaded the Fairtrade Foundation (the NGO responsible for promoting, regulating and accrediting FT products) to recognise local efforts to promote the consumption of FT products by accrediting Garstang as a "Fairtrade Town". This approach of accrediting places of consumption according to local consumption practices, and actions taken to promote them, was then adopted and formalised by the Fairtrade Foundation into a national campaign with strong governmental endorsement (Malpass et al. 2007). The resulting FTT movement has been 
described as "a grassroots campaign to 'grow the Fairtrade market' one community at a time" (Lyon 2014, p. 150).

Becoming certified as a FTT by the Fairtrade Foundation depends upon the following:

- The local (government) council passing a resolution supporting FT, and serving FT coffee and tea at its meetings and in offices and canteens.

- A range of FT products being readily available in the town/city's shops and served in local cafés and catering establishments (with targets set in relation to population).

- FT products being used by a number of local work places and community organisations (again with targets set in relation to population).

- The council actively attracting popular support for the campaign.

- A local FT steering group being convened and maintained to ensure a continued commitment to FT status.

The promotion of FTTs by the Fairtrade Foundation, government and others led to a rapid growth in their numbers to reach 612 in the UK by the start of 2016, with 1116 more established across a further 25 countries (Fairtradetowns.org 2016). The movement has created a substantial network of localised FT marketing systems in which local populations are enrolled through residence and supplemented by visitors and workers (Malpass et al. 2007), empowering consumers to act locally on their ethical concerns (Alexander and Nicholls 2006). This has played an important part in driving FT sales in the UK (the world's largest FT market) to $£ 1.6$ billion, with nine out of ten consumers recognising the FT label (Fairtrade Impact Story 2016). Globally FT's market share is now worth over $£ 6.25$ billion, reportedly assisting 1.6 million farmers and workers across 75 countries (Fairtrade Annual Report 2016).

FTTs are recognised as an innovative form of marketing network (Nicholls and Opal 2005) and as a significant new phase of FT market development (Alexander and Nicholls 2006). However, despite their potential importance in developing ethical markets and connecting consumers to them, relatively few studies have examined their significance. Previous studies consider them from several perspectives including: as a form of marketing network (Alexander and Nicholls 2006); in terms of place-based consumption (Malpass et al. 2007); considering FT support/consumption within FTTs as social practice (Wheeler 2012) and concerning local power relations between FTT groups and other entities Lyon (2014). What we currently lack is an answer to the fundamental question of "How do FTTs operate as an innovative form of place-based ethical marketing network?", and the subsidiary question of "What is the role and nature of activism within them?".
Addressing the first question is the overarching aim of the research endeavour from which this paper comes, whilst it is the second question that this paper specifically seeks to answer.

In exploring the role of activism in developing FTTs as ethical markets, this paper seeks to complement existing knowledge about consumer activism by considering the role that activists can play in influencing a marketing system and the stakeholders within it. It does this through an analysis of the FTT movement as a form of grassroots, activism-motivated marketing and promoting ethical consumption (and through it, production) at a community level. In doing so, FTTs seek to influence and engage a range of stakeholders from within both the local marketplace, and the wider production and consumption system. The paper explores how FTT activists develop relationships and leverage their social capital at a local level in order to promote the increased consumption of globally sourced FT products, albeit with the support of the Fairtrade Foundation as an international social movement organisation (SMO). The paper therefore seeks to improve our understanding of the role that activism can play in facilitating ethical consumption, and what we might learn from FTTs in relation to the development of ethical marketing systems.

\section{Background: Activism and Ethical Business}

Activism is a profound and globalised force for change operating across multiple social spheres including politics, the judicial system, communities and business. It is defined in many ways including as behaviour that advocates a social cause "via any of a large array of possible means, ranging, for example, from institutionalized acts such as starting a petition to unconventional acts such as civil disobedience" (Klar and Kasser 2009, p. 757) or through "everyday actions by individuals that foster new social networks or power dynamics" (Martin et al. 2007, p. 79). Within the business and marketing environment, such activism has the potential to interact with, and influence, a range of business stakeholders. Shareholder (or stockholder) activism represents an important form that includes two quite distinct types (see Guay et al. 2004). The first considers the financial performance, control and structure of firms and typically pursues increases in short-term shareholder value. The second addresses firms' socio-environmental performance through ethical investment and the use of ownership stakes and shareholder resolutions to pressure companies to make improvements.

Ethically motivated shareholder or consumer activism can be considered in the context of broad social movements seeking cultural and ideological change and opposing 
broad phenomena such as globalised business or advertising (Kozinets and Handelman 2004; Shreck 2005). It can involve attempts to change company behaviour through lobbying for regulatory change, shareholder activism or protests (Gopaldas 2014; Hendry 2005; Sandlin and Callahan 2009). The literature on such activism largely focuses on the efforts of SMOs using national-level campaigns to exert pressure through protests and sometimes through partnerships (see for example Hendry 2005 or the reviews by Kourula and Laasonen 2010; or den Hond and de Bakker 2007). Activism can also be expressed through consumption behaviours and decisions, and the most substantial contributions exploring the relevance of activism to marketing mostly relate to consumer activism (e.g. Kozinets and Handelman 2004; Lang and Gabriel 2005; Shaw et al. 2006) including FT consumption (e.g. Shreck 2005).

Marketing scholarship concerning activism has traditionally focused on organised consumer boycotts of particular products, technologies, companies or countries on social or environmental grounds (see for example Smith 1990; Lang and Gabriel 2005). More recently, interest has grown in pro-consumption activism in the form of "buycotts" or "carrotmobs" which actively encourage the patronage of particular products or firms (Hoffmann and Hutter 2012). Such ethical consumption that supports producers engaged in environmental conservation and social justice in developing countries, is seen by some as representing a new form of activism (Bryant and Goodman 2004). However, scholarship on activist campaigns is still skewed towards considering protest and pressure against conventional companies and market offerings, rather than in favour of more ethical alternatives. A simple if unscientific demonstration of this disparity comes from inputting into the research tool Google Scholar, the terms "consumer boycott" (which in October 2016 returns 4740 entries), and the alternative of "consumer buycott" (which returns 18). Activism can also be understood at the level of individual consumer behaviour through the lens of political consumerism, explained by Micheletti (2003, p. 2) as follows:

It represents actions by people who make choices among producers and products with the goal of changing objectionable institutional or market practices. Their choices are based on attitudes and values regarding issues of justice, fairness, or non-economic issues that concern personal and family well-being and ethical or political assessment of favourable and unfavourable business and government practice.

Broadening and harnessing such political consumer activism has been the primary aim of FT marketers and a key focus for researchers interested in FT markets (e.g. Doran 2009; Kim et al. 2010; Shreck 2005).
Activism relevant to marketing and market development, but not involving consumption directly, can also include an individual's role as a citizen through petition signing, letter writing (to companies or legislators), fund raising, joining groups or protests, or trying to influence the attitudes or behaviours of others (Seguin et al. 1998). Activism therefore can promote change through activist citizen-consumers responding to an issue, and through activism amongst citizens responding to an issue in ways that may directly target, or indirectly influence, consumers. From the perspective of promoting ethical consumption, we appear to know far more about the former than the latter. There are also opportunities for research that helps us better understand activism in terms of its effect at a local rather than national or international level, and the potential for activism to go beyond directly persuading either producers or consumers to change their behaviours, and instead to seek to actively alter the marketplace environment in ways that support such changes.

O'Shaughnessy and Kennedy (2010) additionally subdivide activism into two dimensions. The first is traditional activism involving consumer response and/or citizen participation in protests or public action campaigns. The second is relational activism, a less obvious form of influence that involves networking between like-minded people concerned about an issue. Although apparently less proactive, such activities underpin traditional activism and, in an increasingly digital and interconnected world, are becoming more influential and effective. However, as O'Shaughnessy and Kennedy (2010, p. 551) note, relational activism represents "an overlooked and under-recognized dimension of traditionally defined 'activism", despite its potentially important role in bridging the private and public spheres. This would also appear to hold true for research relating to activism in the context of promoting ethical consumption and market systems.

\section{Fairtrade Marketing: From Product to Place- Based Activism}

Products marketed to consumers as FT accredited, with an emphasis on producer communities benefitting from a "fair" and stable price for commodity products, have existed for over 40 years (a history encapsulated by Doherty et al. 2013). Although normally associated with the social equity dimensions of the sustainability agenda, FT accreditation standards also contain measures linked to the protection of environmental quality. Therefore, FT is held up as a model of ethical consumption due to its developmental agenda being achieved through a market-driven commercial model that embeds values linked to ethics, 
community and environmental sustainability into the appeal to consumers (De Pelsmacker and Janssens 2007; Doherty et al. 2013; Golding and Peattie 2005; Jaffee 2007). This appeal is also supported by direct evidence of FT's positive impact on producer community quality-oflife (Geiger-Oneto and Arnould 2011). This is not to say that FT is uncontested and beyond criticism. The debates about the economic, social and sustainability benefits of FT are beyond the scope of this paper, but are thoroughly reviewed by Smith (2009) who notes that a majority of criticisms are rooted in economic theory rather than ethics, lack specific evidence and tend to be rhetorical in nature.

The development of FT markets is framed by Hira and Ferrie (2006) as remarkable in being driven by an activist community, and they highlight the multiple roles played by activists in market development. These include acting: as the catalyst behind the establishment of the market, as a target market in themselves, as guardians of certification systems, as advocates for government support, as promoters of FT as a form of standard, as market innovators, as co-creators of research about FT and as a force to keep other system stakeholders accountable and responsive. The development of the FT market is set out in detail by Doherty et al. (2013) and has gone through distinct phases or eras (Child 2015; Davies 2009; Golding and Peattie 2005; Nicholls and Opal 2005) beginning with an era of "solidarity selling", notable for relatively poor quality products (particularly coffee) marketed through unconventional channels. It represented a distinct market niche in which FT movement activists marketed directly to consciously activist consumers.

The "mainstreaming" era that followed generated rapid growth in FT consumption, reflecting a greater emphasis on marketing management, improvements in product quality, packaging and branding and increased access to supermarket channels (Child 2015; Davies 2009; Doherty et al. 2013). Mainstreaming saw FT become an element of the product selections of global brands such as Starbucks, Nestlé, Costco and Cadburys (Jaffee 2010; Doherty et al. 2013) and interest broaden beyond specifically FT activist consumers to a broader category of political consumers (Wilkinson 2007). The introduction of "choice editing" in certain contexts (such as Marks \& Spencer coffee shops) has even taken FT consumption beyond the realms of activism by reducing consumer choice in favour of FT. Some argue that this creates "corporate activism", a situation in which the agendas and ideologies of social activists and businesses are in harmony rather than opposition (Paynton and Schnurer 2010). Mainstreaming creates a challenge for FT marketers in balancing the pressures for FT to further expand in order to do more good, yet remains true to FT's ethical roots in order to protect its unique selling proposition (Child 2015; Davies 2009; Jaffee 2010).
In addition to the greater penetration of FT products in markets such as coffee and bananas that mainstreaming brought, the breadth of accredited products also expanded to include handicrafts, flowers, personal care products, wine, cakes, clothes and tourism products. The idea of expanding the FT label from products to places followed from the success of the activist group in Garstang in systematically lobbying their local retailers, organisations and public sector to supply and consume more FT products in the town. This success acted as a catalyst for their leader, Bruce Crowther, to then lobby the Fairtrade Foundation to accept the principle of awarding places (such as towns and cities) FT status. Allowing places to achieve FT accreditation was viewed as a key to scaling up activist operations and thus develop promotional, purchase and consumption opportunities at a local "community" level.

Alexander and Nicholls (2006) see FTTs as the driver behind a new "place-based" era of FT marketing appealing to consumers who have "weak ethical concerns, but are still engaged with issues, particularly those that affect their local area. The marketing approach to this large segment focussed on empowering them to act locally on their ethical concerns" (p. 1244/1245). In most cases, the pursuit of FTT status represents a formalisation, integration and extension of the type of grassroots activism that already exists within towns through churches, schools and community groups (Nicholls and Opal 2005). It is FTT's identity as a grassroots movement driven by local activist groups, rather than being a "manufactured" marketing strategy designed by an alternative trading organisation such as the Fairtrade Foundation (although they do provide marketing support), that is seen as crucial to their success (Alexander and Nicholls 2006). The accreditation requirement that a local FTT steering group is established to secure buy-in from the local community and ensure an ongoing commitment to FT status amongst local stakeholders (Lyon 2014), also effectively enshrines a key role for activism within the FTT movement that goes beyond the role of the consumer.

This paper seeks to further our understanding of FTTs as an ethical marketing phenomenon by exploring the role played by activism and by activists as marketing system change agents. This includes their role in promoting FT consumption and production through the building of marketing relationships, and by creating opportunities to apply pressure and support at a micro- and meso-level to increase the awareness, availability and consumption of FT products locally.

\section{Methodology}

Davies (2009) and Child (2015) highlight that many papers addressing FT are normative and descriptive, and that our understanding of FT is held back by a lack of empirical 
papers providing deep contextual understanding. This study seeks to address this by applying Grounded Theory (GT), the qualitative and interpretive methodology pioneered by Glaser and Strauss (1967), which is widely used across social science, although under-used in marketing studies (Goulding 1998). It is recognised as particularly suitable for researching emerging phenomena where preexisting theory or rich data is lacking, as is the case with FTT (and the methodology and its benefits are discussed in much greater detail in Samuel and Peattie 2015). GT allows the exploration of the social world of the FTT movement from the viewpoint of key stakeholders involved in its construction and implementation within particular towns. Qualitative data were captured from the social situations, views, motives, interactions, interpretations and everyday actions of insiders (Blaikie 2000), in this case primarily the activists involved in promoting FTTs, considered both individually and collectively. In this way, qualitative research is able "to explicate the ways people in particular settings come to understand, account for, take action, and otherwise manage their day-to-day situations" (Miles and Huberman 1994, p. 7).

\section{Data Collection and Analysis}

The project involved three elements of qualitative enquiry (as illustrated in Fig. 1), all subject to approval from the relevant University's Ethics Committee.

Firstly, ethnographic involvement over three years within a FTT group and membership (with permission to record and research) of its Steering Group. Official minutes and researcher journals of meetings and general observations acted as data sources. Secondly, 29 semi-structured interviews were conducted in 11 different FTTs across the UK. This incorporated both the longest standing group in Garstang, and a newly established one in Carmarthen. The sample of FTTs visited, and the participants interviewed, followed the recommendations of other participants who were asked to identify suitable FTTs and FTT activists. For example, the Garstang group recommended Keswick as a highly proactive group "worth talking to". By allowing the research participants some ownership of the research sample (i.e. telling us who and where to go to next and why), this helped to capture appropriate thick biographical interpretations from those most actively involved (Denzin 1989). The FTT activists represented within the study were varied in terms of their ages, professions, ethnicity and backgrounds. There were marginally more female than male interviewees, with ages ranging from six interviewees in their twenties, to three in their sixties and one in their seventies. The most widely shared trait amongst respondents is the expression of political leanings and affiliations best described as left or left of centre.
Table 1 presents a breakdown of the FTTs visited (in chronological order) and the activists interviewed.

Finally, a serendipitous development (something GT encourages) allowed for three days to be spent with a founder of the FTT movement, learning more about the development of the movement and its application in their home town.

Each stage provided rich qualitative data via interview transcripts, steering group minutes, researcher journals and other documents totalling 110,432 words of data. Upon collection, data were immediately line-by-line coded (by hand), and this process helped classify activist acts and outcomes by coding each line through the process of asking "what is happening here?" (Strauss and Corbin 1998). This was followed by focussed coding to condense and understand the data by constantly comparing experiences, actions and interpretations across all datasets to identify themes and relationships (Strauss and Corbin 1998). Coding was complemented by the creation of memos to capture thoughts, facilitate contrasts and identify connections across the data. Analysis of the codes and memos led to the creation of three core categories, one of which was "Pressure and Support" detailing the use of FTT activists' social capital and social networks to promote FT (effectively complementing the analysis by Davies (2009) and Davies and Ryals (2010) relating to FT suppliers). The findings presented below relate to that core category.

\section{Findings}

Achieving and maintaining accreditation as a FTT reflects a range of forms of pressure being applied, and support provided, by the activists within the local steering groups, acting both as individuals within their own social spheres and collectively within the local community. Table 2 provides a summary of the key tactics adopted by FTT activists and the broad strategies these reflect, illustrated with example line-by-line codes from the data analysis. The key insights that emerged about FTT steering groups as activists, and the four overarching strategies they adopted, are discussed below.

\section{The FTT Steering Group as Activists}

Research identifying the success factors behind FT highlights a range of issues and stakeholders including activists (Brown 2011; Hira and Ferrie 2006), social capital (Davies and Ryals 2010), social networks (Davies 2009) and consumer involvement (Dubuisson-Quellier and Lamine 2008; Alexander and Nicholls 2006). FTTs have also been considered as one of the success factors (Nicholls and Opal 
Fig. 1 Researching the marketing dynamics of Fairtrade Towns (Samuel and Peattie 2015)
The Marketing Dynamics of Fairtrade Towns: Using Grounded Theory

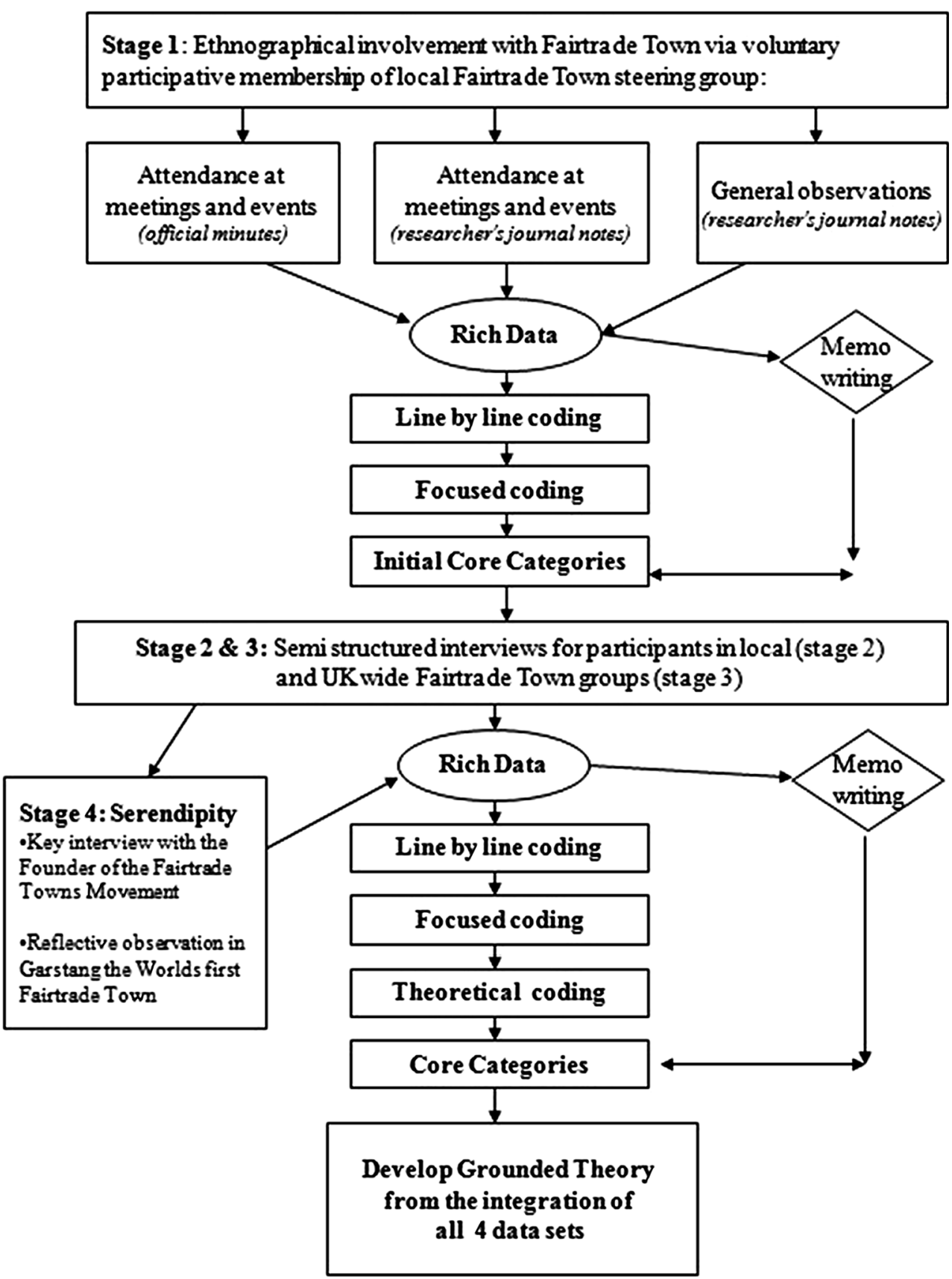

2005; Barnett et al. 2011; Lyon 2014), but the steering groups behind FTT have received little explicit attention within research, beyond a mention by Malpass et al. (2007). Although activism within a FTT will go beyond those involved in the steering group, not least in terms of consumer activism through FT consumption (explored by Wheeler 2012), the steering groups represent the key focus of beyond-consumer activism in FTTs.
Narratives that emerge from the data represent a belief that steering groups are "instigators of action" making connections between the macro-level ideology of the Fairtrade Foundation and companies' certified products, with the day-to-day life that exists within a town:

I see the role of the steering group as being that of intermediary between high level stuff and on the 
Table 1 Research sample and snowball trajectory

\begin{tabular}{|c|c|c|}
\hline $\begin{array}{l}\text { Fairtrade town } \\
\text { (place) }\end{array}$ & Interviewees (People) $(\mathrm{M}=$ Male, and $\mathrm{F}=$ Female $)$ & $\begin{array}{l}\text { Recommended (Fairtrade Town) Interview } \\
\text { Trajectory }\end{array}$ \\
\hline Cardiff & $\begin{array}{l}\text { Chair of Cardiff FTT \& Shop Owner (F) } \\
\text { Social Enterprise Worker (F) } \\
\text { Student (M) }\end{array}$ & $\begin{array}{l}\text { Hereford } \\
\text { Merthyr Tydfil }\end{array}$ \\
\hline Carmarthen & $\begin{array}{l}\text { University Chaplin (M) } \\
\text { NGO Worker (M) } \\
\text { Student (F) }\end{array}$ & Swansea \\
\hline Garstang & $\begin{array}{l}\text { Local Councillor }(\mathrm{F}) \\
\text { Vet }(\mathrm{M}) \\
\text { Teacher }(\mathrm{F}) \\
\text { Soroptimist }(\mathrm{F}) \\
\text { Retired Teacher }(\mathrm{F})\end{array}$ & $\begin{array}{l}\text { Keswick } \\
\text { Oundle }\end{array}$ \\
\hline Swansea & $\begin{array}{l}\text { Sustainability Centre Manager (F) } \\
\text { Teacher (F) } \\
\text { Traidcraft Representative (F) }\end{array}$ & Merthyr Tydfil \\
\hline Hereford & Vicar (M) & $\begin{array}{l}\text { Worcester } \\
\text { Bridgnorth }\end{array}$ \\
\hline Keswick & NGO Worker (M) & Millom \\
\hline Worcester & $\begin{array}{l}\text { Local Councillor (M) } \\
\text { Cooperative Store Manager (M) } \\
\text { NGO Volunteer (F) } \\
\text { Self-Employed Gardener (M) } \\
\text { Traidcraft Representative (F) } \\
\text { Teacher \& Catholic Agency for Overseas- Development Volunteer } \\
\text { (F) } \\
\text { Retired Local Council Worker (M) } \\
\text { Teacher (F) }\end{array}$ & \\
\hline Bridgnorth & NGO Volunteer (F) & \\
\hline Merthyr Tydfil & $\begin{array}{l}\text { Sustainability Officer: Local Authority (M) } \\
\text { Lecturer (M) }\end{array}$ & \\
\hline Oundle & Church Representative (F) & \\
\hline Millom & Retired Teacher $(\mathrm{F})$ & \\
\hline
\end{tabular}

ground stuff, because that is the only way things are going to change.

$$
\text { University Chaplin (Carmarthen) }
$$

A number of metaphors were used by respondents to describe a steering group's role including "catalyst", "engine" and "beating heart". Members viewed their mission as increasing FT awareness, knowledge, availability and consumption within "their town". This frames their role in terms of influencing "placements of practice" (Amin 2002, p. 391) to develop social interactions in particular places for the purpose of promoting and consuming more FT products:

To get people in the community involved in Fairtrade and to raise their awareness of Fairtrade and to ensure there are more Fairtrade goods in the shops and being used by the community.

\section{NGO Worker (Carmarthen)}

It was clear from the interviews that steering group composition partly reflects members' values and enthusiasm for FT, and sometimes their previous involvement in supporting it more informally. As Table 1 indicates, many group members had professional links to international development, education, sustainability policy or churches, which were all potential sources of previous engagement with FT. Group membership is also influenced by strategic decisions to co-opt individuals whose perceived community roles, networks and social capital might be leveraged to promote FT. The diversity in FTT members' social capital and skill sets therefore helps to determine the role that individual 
Table 2 Summary of key findings

Activist tactics
Activists personally promoting FT through lifestyle, personal
interaction \& conversation
Integration of the benefits of FT's developmental achievements
incorporated into religious and educational practice

ntegration of the benefits of FT's developmental ach
incorporated into religious and educational practice

Activists' social capital and skill sets determine the role they play and informs the recruitment of other members and advocates

Activists' social capital used to "build bridges" with people who can "get things done", "open doors" or "provide help and assistance"

Diversity in FTT group membership called upon to maximise influence

Engaging local government, places of worship, education and organisations with synergistic resonance

Connections with established SMOs with a stake in FT such as Oxfam, Tradecraft and Christian Aid

Activist shifting focus from the retail and catering businesses, to improving the supply of FT provision within the premises of other organisations and institutions

Integrating FT into a broader sustainability agenda
Broad strategy

Influencing consumers

Influencing consumers

Bridging the meso and

Fairtrade

Influencing consumers

Pressuring commercial sector

Bridging the meso and institutionalising

Fairtrade

Pressuring commercial sector

Influencing consumers

Bridging the meso and institutionalising

Fairtrade

Influencing consumers

Pressuring commercial sector

Bridging the meso and

Fairtrade

Bridging the meso and institutionalising

Fairtrade institutionalising institutionalising

Example initial line-by-line codes

Promote the ethos of FT amongst their social network

Personally purchasing FT in order to always encourage others

Get people to try FT to influence future purchase/ discussion

Intermediaries between high-level FT ideology and consumption changes amongst organisations and consumers

Promotion of FT in church sermons and school lesson linked to social justice/sustainability

Individual skills of people in the town being utilised to facilitate FTTs' activities, build capacity and knowledge

Individual skills of people in the town being utilised to facilitate FTTs' activities, build capacity and knowledge

Opportunity taken to further promote FT as part of certain peoples' background and job role

Members' interests \& friendships used to get voluntary sector involved

Individual skills of people in the town being utilised to facilitate FTTs' activities, build capacity and knowledge

Opportunity taken to further promote FT as part of certain peoples' background and job role

Key influencers (such as teachers, academics and council leaders) are seen as essential to FTT success

Local council link making FT promotion possible to headmasters and some schools

Flagship employer needed

Push to make other organisations go for FT status (local university emphasis)

Knowledge and experience of FT coming from Universities and other places of work and socialisation

Bridging the meso and Experience and kudos of SMOs work to the group institutionalising Fairtrade SMOs help supply FT products for taste trials

Interconnecting activism

Pressuring commercial sector

Organisations from all three sectors (commercial, public, third sector) supporting FTTs

Bridging the meso and Flagship employer needed institutionalising Fairtrade

Push to make other organisations go for FT status (local university emphasis)

Interconnecting activism
Eco-schools link

Council sustainability officers' engagement 
activists, or other organisations they belong to, may play. For example, teachers may be asked to produce and/or distribute learning materials and link with schools; council officials may produce letters for distribution via their database; community development workers may volunteer to support community groups and events; employees of The Co-operative and Christian Aid may provide free samples of products and promotional materials from their organisations. This emphasis on building and exploiting connections reflects Nicholls and Opal's (2005) application of Actor Network Theory to FT marketing. New nodes (people who represent or have skills sets) appear to gain functional meaning and significance due to their ability to effectively apply their representation or skills to specific marketing dynamics:

I'm just one member of the group really, I don't think that I have taken any leading role more than being part of the group. But informally, through the meetings I have been able to contribute our experiences at Christian Aid to the group... I have more information than some of the others on how it affects the poor. Hopefully I can contribute that way.

\section{NGO Worker (Carmarthen)}

Diversity in steering group membership is viewed as important to maximise their potential influence. There were two slightly contradictory concerns expressed about group membership, commitment and growth. One reflects the common experience of members "coming and going" resulting in a perceived lack of a cohesive group identity created by members "not knowing each other". The other is a perceived need for "new blood" to develop the group, usually identified as younger people. These findings suggest that Tallontire's (2001) observation that FT consumers are to some extent dominated by "alternative" and ageing people may also apply to the activists within FTTs. Younger people are identified as having a different skillset (particularly online communication skills viewed as important in helping to further relational activism within the community), and social connections that can generate new ideas and open up new connections. They are also seen as a key segment of the market that a place-based approach may be able to better access (Alexander and Nicholls 2006). There appears, therefore, to be an underlying worry that a key node in Nicholls and Opal's (2005) actor network is underrepresented potentially limiting the emergence of new dynamics from new interactions:

It would be nice to have some new people, that's always a goodie. Young people would be good because it gives it more flexibility....Just getting new people to pick up and run with the agenda will be a good thing. Vicar (Hereford)
Get another 50 members and become younger. We have talked about the make-up of the group and we have attracted younger members to the group but they don't stay. I think once a group stays together for a long time to a certain extent it becomes self-perpetuating and it becomes difficult to get new people in. We have had difficulty recruiting new people and we have had brainstorming sessions about how we can get more people.

Self-Employed Gardener (Worcester)

\section{Strategy 1. Pressuring the Commercial Sector}

The second FTT accreditation criterion is that "a range of Fairtrade products are available locally" (Fairtrade Foundation 2016). Therefore, seeking to pressurise retailers has been a key strategy of FTT activists. The movement's early growth emphasised the use of high street audits to assess FT availability, which provided opportunities to highlight the commercial opportunity that stocking FT products might represent:

Maybe, even if it's just down to badgering your local shop and supermarket to stock more things, which is how it sort of starts, because people will only buy things if they can access them, they are not going to go miles out of their way to buy a Fairtrade version of something. So, maybe the challenge is to keep getting local shops and other organisations that don't stock them to keep going really.

\section{Social Enterprise Worker (Cardiff)}

In some cases, FT literature was distributed to retailers during the audit process, and the information gathered used as the basis of a FT shopping directory for the town.

The relationship between FTT activists and commercial retailers and producers has evolved with the mainstreaming process. Once brands like Cadbury's Dairy Milk or Kit Kat became widely available across a range of retailing formats, and retailers such as Starbucks adopted FT, the emphasis on auditing and pressuring mainstream retailers reduced. This development risks undermining activists' sense of identity and mission. Lyon (2014) describes one impact of the "strategic marketization" of FT as leaving activists with an uncomfortable sense of providing free labour and marketing help for major corporate players. The response of the UK activists in this study was a pragmatic one, of shifting their focus from the obvious retail and catering businesses to instead promote the provision of FT refreshments within workplaces, particularly premises that the public visit including dentists, post offices, hairdressers, tourism offices and solicitors. In this way, the activism evolved to become even more locally embedded rather than 
just targeting consumers as the final link in international retail and distribution chains. Although from a conventional supply chain perspective, mainstreaming appears to have shifted the responsibility for the development of FT and its marketing from activists to marketing professionals, in practice, FTTs have provided a new role for direct activist involvement in the overall FT movement. This represents part of what Lyon (2014) characterises as activists' efforts to "reclaim" the FT agenda postmainstreaming.

\section{Influencing Consumers}

Although the core strategy of FTT activists often focuses on generating support amongst retailers, local government and other local organisations where they can have the greatest potential impact (Lyon 2014), many activists see a key role for themselves in promoting FT consumption amongst individuals. This is mostly through their private circle of family, friends and work colleagues, involving the conspicuous consumption of FT products to set an example (including through displaying products within the home) and the giving of FT gifts. In doing so the activists reflect Clarke et al.'s (2007, p. 593) notion of the development of FT consumption as going beyond the enrolling of people as consumers to addressing them as "members of varied social networks who will not only consume ethically but also initiate discussion with friends, family, co-workers and others". Wheeler (2012) found that such social networks within FTTs are crucial in terms of people being introduced to, and becoming involved with, FT consumption. Participants in the study were clearly aware of the value of using different types of social network as vehicles to promote FT. The quality of FT products, their developmental benefits and the ease of brand switching are all woven into everyday conversations as a form of word-of-mouth marketing. In some cases, a willingness to engage with consumers on a one-to-one basis extended beyond private circles:

As an individual, I tend to go around enthusing people and I' $m$ one of these people that wherever I go and if I tend to see people drinking Nescafé or not Fairtrade goods I will point out about the other goods and ask people why they are not using Fairtrade.

Student (Carmarthen)

\section{Bridging the Meso and Institutionalising Fairtrade}

Beyond the normal marketing perspective of influencing retailers to stock, and consumers to purchase, FT products, activists also target a range of community institutions to build support. Doing so involves using activists' social capital to "build bridges" with people who can "get things done", "open doors" or "provide help and assistance". Activists value the potential of "distant acquaintances" (Granovetter 1973), to further bridge their social capital into meso-level marketing activities. For example, it was common in steering group meetings to hear members voluntarily declare links to relevant people they may tenuously know, believing they could add value to FTT activities. On a meso-level, steering group members' social capital (recognised through the bonds they have, and the bridges and links they can build within workplaces, organisations and "their place") reveals itself as a key marketing resource for FTTs:

Because I work for the college the other day I was looking for Fairtrade sports equipment to try and give some information to the sports department to just say please look at these options and if there is anything you want I would possibly order it for them.

Teacher (Garstang)

Meso-level activism within FTTs attempts to increase individual knowledge about, and consumption of, FT by connecting with local organisations and groups. This represents both an institutionalising of FT at a local level, and a means of empowering local citizen-consumers by making them feel connected to something bigger (Wheeler 2012). This approach also reflects Seyfang and Haxeltine's (2011, p. 384) argument that grassroots networking activities to develop markets for more sustainable products work best when they "embrace many different stakeholders, who can call on resources from their organisations to support the niche's growth". A key focus for this was local government, since their support, if only in the form of a pledge to serve FT refreshments within council premises, is one criterion for accreditation. Although the extent of council buy-in varied, a range of types of marketing support was provided, including making council premises available for events, opening up channels for FTT (such as allowing them a presence at council run farmers' markets) and helping to develop marketing materials including press releases, display units and directories.

Churches and educational establishments were other institutions approached to support FTT initiatives. This support could be through the integration of the benefits of FT from a developmental point of view into the message (either religious or educational) that they provide. For schools, efforts to integrate sustainable development into the curriculum provide FTT activists with opportunities to speak in class or provide Fairtrade Foundation educational materials. The involvement of churches is natural given their instrumental role in FT's origins and the observation that faith-based activism can have close links to new social movements challenging the established capitalist system (Kozinets and Handelman 2004). Doran and Natale (2011, 
p. 6) identify many examples of faith-based organisations "incorporating fair trade into their social and ceremonial activity":

I quite often preach on Fairtrade as an ethical issue as a response to other gospel readings and a call for social justice. In fact, I did it on Sunday. I just mentioned it obliquely in a Harvest service I was giving.... I was trying to get the congregation to think about their own behaviour as consumers and how they might be able to help producers in developing countries who themselves may be struggling to feed their families and so on.

$$
\text { University Chaplin (Carmarthen) }
$$

These institutions also underline their commitment to FT through actions such as churches serving FT refreshments (including in some cases communion wine) and schools backing up classroom endorsements by also serving FT drinks in the staffroom.

\section{Interconnecting Activism}

FTT activists also operate by connecting with more established SMOs with a stake in FT, such as Oxfam, Traidcraft and Christian Aid. Often this interconnection is achieved through individual activists having multiple layers of identity that span across SMO membership, or by using meso-level social capital that bridges to SMO members. Such connections can draw upon valuable campaigning and lobbying experience and knowledge, and SMOs are perceived to support FTT initiatives in several ways. Partly, they act as a policing mechanism in line with Hira and Ferrie's (2006) descriptions of pro-FT activists' roles as guardians of certification systems and as a force promoting accountability within the market system. This helps to maintain a focus on the Fairtrade Foundation's remit and the marketing of FT products:

Some members from (Organisation $\mathrm{X}$ ) are very keen on doing things properly (Member $\mathrm{X}$ ) is very keen to emphasise to the group that when we campaign we must stick to only promoting the Fairtrade logo because everything that claims to be fairly traded or ethical is not valid. It must always carry the logo.

\section{Student (Carmarthen)}

This helps to avoid a broadening into non-certified "ethical" products and a dilution of the trade justice message which some see as a risk of mainstreaming strategies (Around 2006).
SMOs also provide practical help and resources including employee time, access to products and testers to use at events, access to marketing materials (such as posters or post cards), access to their network of campaigners and supporters or speakers to present at events. FTTs' alliances with such SMOs are perceived as adding structure, kudos, professionalism, social capital, campaign momentum and tangible value to FTT activity. It suggests that within a local context, activism can best be understood in terms of a network of influence in which activist agendas can compete (Lyon 2014), but can also work synergistically.

As well as connecting to other organisations within their community, FTT activists frequently recognise and pursue the benefits of connecting to a wider sustainability agenda:

Fairtrade can actually be a part of active citizenship... You know if we're going to talk about sustainable local economies, we're going to talk about sustainable domestic farming, then we as Fairtrade campaigners, within a bigger picture, have to be talking about Fairtrade and local. And we have to be engaging with these issues of sustainability, and we want to do that.

\section{NGO Worker (Keswick)}

Integrating FT into a broader sustainability agenda can also be instigated by local councils by allocating responsibility for FT to a Local Agenda 21 Officer, or to council sustainability teams. This paid dividends for FTTs, as many councils remained committed to promoting FT because it was contextualised as integral to their sustainability strategy. FTT activists' ability to connect FT consumption to a wider sustainability agenda can be reflected in policies linking FT and local consumption through one voice. For example, Carmarthen council during their campaign to become a FTT presented seven pledges to become more sustainable, one being to "shop ethically and buy Fairtrade and locally produced goods" (Carmarthenshire Sustainability 2011). This framing of both FT and supporting local produce within an overarching sustainability agenda with institutionalised local government support was potentially helpful in avoiding the US experience reported by Lyon (2014). There the local and FT agendas tended towards the antagonistic, with determined "localvore" activists opposing FT's international and developmental agenda in favour of a low-carbon, local farming one. This led some FTTs Lyon studied to seek different affiliations, such as with the slow food and slow fashion movements. Other campaigns reported offering carbon offsets for FT products in order to deflect carbon emission-based opposition. 


\section{Fairtrade Town Activists-Future Research Opportunities}

In summary, the empirical data gathered in this research allow a number of propositions about the role and work of FTT activists to be developed, which could provide subjects for further research into FTTs as an activist-driven strategy to promote ethical consumption and production:

(1) FTT steering groups are empowered to take on the role of locally placed marketers and "information brokers" for the Fairtrade Foundation and FT certified products.

(2) FTTs depend on demographic, lifestyle and behavioural diversity in their steering group membership to maximise their leverage and utility in influencing FT consumption choice.

(3) FTT activists' sense of belonging to a place is important in developing and connecting the places and spaces of towns and cities in the UK to function as key nodes in an actor network to develop and promote FT consumption.

(4) FTT activist success demonstrates how a "resources-deficient group" can exert influence "through strategic networking that engages those necessary and the numbers necessary to trigger change" (Hutchens 2009, p. 80).

(5) FTT activists' "thicker personal identities" (Barnett et al. 2011, p. 23) are used to engage microand meso-level social capital in place-based activism within FTTs.

(6) FTT activists use individual conspicuous consumption as a medium to promote FT consumption in the social places where they interact with their circle of family, friends and work colleagues.

(7) FTT's alliances with SMOs add structure, kudos, professionalism, social capital, campaign momentum and tangible value to their marketing activities.

(8) FTTs demonstrate that within a local context, "activism" is best understood in terms of a network of influence that utilises activists' social networks.

(9) FTT activists connecting FT consumption to a wider sustainability agenda within their local communities has paid dividends by encouraging local councils to commit to promoting FT positioned as integral to the pursuit of sustainability.

(10) FTTs take advantage of the neglected relevance of institutional consumption and demonstrate the significance of moving the actions and activities of ethical consumption into the meso-level of place.

Overall as a form of place-based marketing (Alexander and Nicholls 2006), FTTs are developed through beyond- consumer activism that promotes localised FT provision and consumption by leveraging and linking a number of the success factors behind FT's broader growth, including consumer involvement, activism, social capital and social networks (Alexander and Nicholls 2006; Brown 2011; Davies 2009; Davies and Ryals 2010; Dubuisson-Quellier and Lamine 2008).

\section{Discussion}

Wilkinson (2007, p. 223) describes FT as "a social movement for which new terms of trade represent a strategic tool for the promotion of development and social inclusion" which employs advocacy to "make trade fair" in international fora, whilst also pragmatically growing the market through campaigning work that includes FTT, alongside FT Week/Fortnight campaigns and efforts to influence public procurement policies.

The activists behind FTTs develop and implement strategies to promote the availability and consumption of products from commercial companies (both social enterprises and conventional firms that have embraced FT), yet they are not a formal part of that commercial marketing effort. Their agenda is guided by the remit, marketing support and accreditation processes of the Fairtrade Foundation, yet they are effectively self-organising local voluntary groups that exist independently from such global stakeholders. They engage with other local stakeholders ranging from individual consumers through to branches of international retailers, and exert their influence though a web of connections with other local organisations, and by exploiting their existing social capital and social connections. The resulting impacts of their activism, in terms of network building and influencing market power dynamics (Martin et al. 2007) are summarised in Fig. 2. This pattern of influence can be contrasted with that most typically associated with the role of (specific issue) activism in the operation of markets. Such relationships generally focus on a dyadic confrontation, with activists from SMOs opposing the activities of producer organisations and seeking to act as a barrier between producers and consumers through protests, boycotts and other approaches to pressurising corporations to change their behaviours. FTT activism involves a multi-stakeholder engagement strategy aimed at facilitating consumption and improving the operation of a market at different levels of the overall supply chain, in both consumer and organisational markets.

In furthering our understanding of this network, and the catalytic role that FTT activists play, Nicholls and Opal's (2005) choice of Actor Network Theory as an approach to understanding FTT represents a key method by which research in the field could usefully be taken forward. 


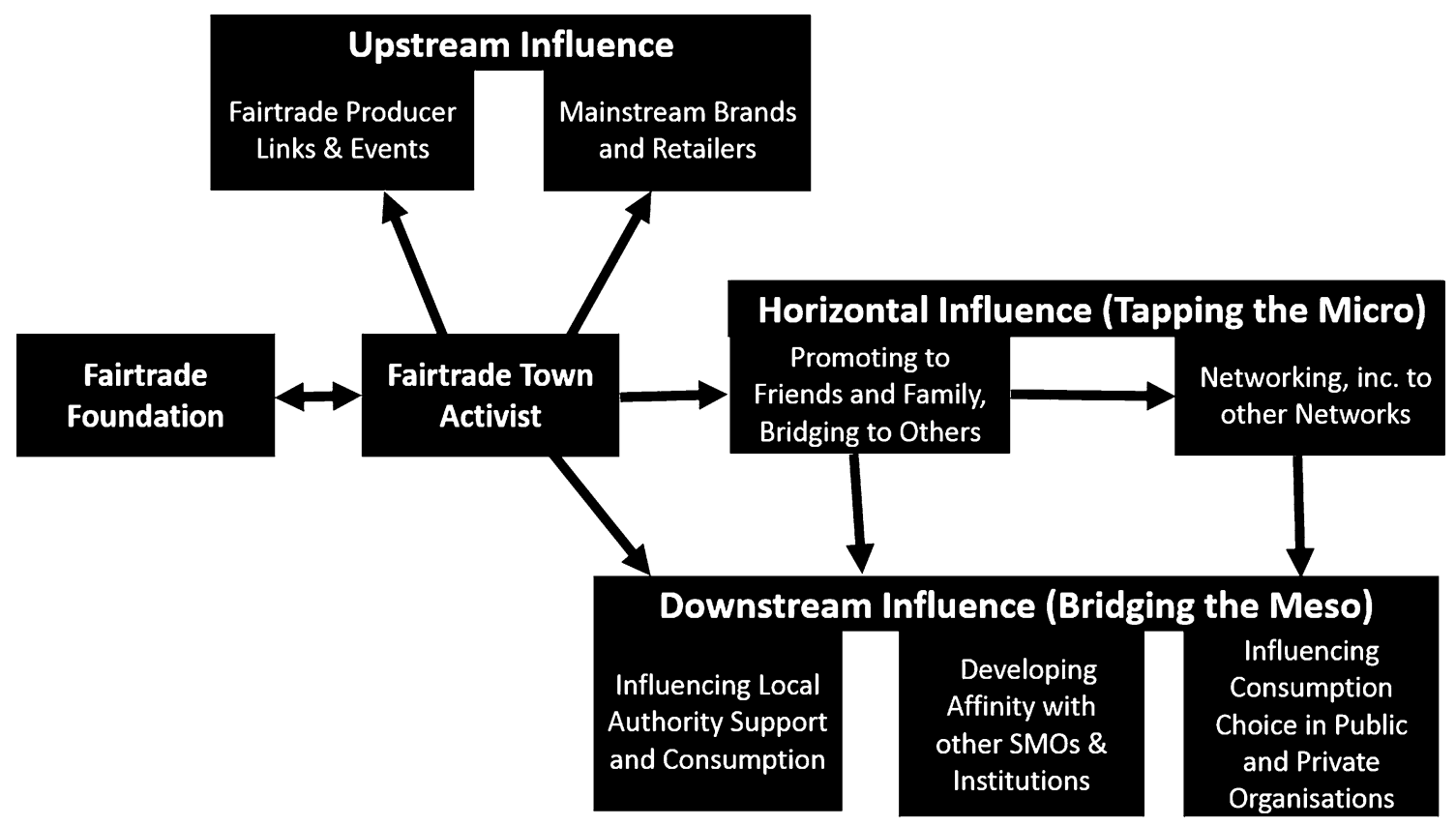

Fig. 2 Mapping the influence of the Fairtrade Town Activist

The complex network of interconnections that FTT activists develop and utilise to promote FT also represents a different type of marketplace activism dynamic to that described by Hendry (2005) in considering the influence of "activist stakeholder organisations" in promoting more ethical corporate behaviour. The power dynamics that Hendry observes concern the attempts by SMOs to directly influence businesses through resource-dependence relationships, according to the interdependence and relative power of the firm and the stakeholder organisation. FTT activism is less clearly a power and influence relationship between two organisations, or even types of organisations, based on resources. It is more activism that embraces the whole market system and seeks to influence players within that system through common interests and identities, and the promotion of ethical behaviours amongst a range of other marketplace stakeholders (as outlined in Fig. 2).

Since the exercise of influence was a recurring theme in the role and work of FTT activists, the findings inevitably reveal interactions and influences at different levels that are overtly political in nature. This research did not however approach FTT from a political perspective, nor actively seek out the political aspects of FTT activists' work, and these dimensions are more systematically explored by Malpass et al. (2007) and Lyon (2014). As FTT activists' sought to exert influence upstream (macro), horizontally (micro) and downstream (meso), politics and political leanings invariably played a part in the resulting dynamics. For example, success in exerting influence downstream to encourage local councils to support and consume FT tended to be greatest where councils had "party" political leanings to the left of centre. In some cases where councils were particularly enthused, a power struggle then emerged for leadership of the local FTT initiative. At a more microlevel, internal FTT group politics sometimes proved the source of activist-on-activist conflict, played out through debates about the need to maintain the "purity" of FT products and focus on the developmental goals of FT in the face of mainstreaming pressures (Jaffee 2007). The politics of place (in line with the findings of Malpass et al. (2007)) also produced conflicts within some FTTs. This was particularly noticeable in towns with a strong connection to farming, where activists had to respond to the political debate surrounding falling commodity prices and relative local poverty, reflecting the experience of Lyon (2014). Resolution in many of these communities was achieved through activists' familiarity with their town and its identity, and having the ability to develop synergistic strategies, for example, exhorting consumers to "use their LOAF" an acronym for "local and/or fairtrade" consumption.

In recognising that the marketing dynamics of FTTs are played out through participant ownership, symbolic interaction and individuals' lived experiences, this study's data confirm the findings of Barnett et al. (2011) and Wheeler (2012), and also frame participation in FTTs as much more than just an act of ethical consumerism. Participants' clear understanding of "place belonging" (Barnett et al. 2011, p. 189) and being "in place... mobilizing devices for collective action" (Malpass et al. 2007, p. 634), sees them aligning their actions and thoughts much closer to conceptualisations of political consumerism (Micheletti 2003; Clarke et al. 2007; Nicholls 2010) and consumer 
citizenship (Seyfang 2005), but adding in a dimension of local solidarity to complement the appeal for greater global social justice. Just as Barnett et al.'s (2011) research suggests, FTTs in this study demonstrate themselves as an arena of consumer citizenship by moving beyond the traditional marketing paradigms of promoting to individuals, through developing and promoting activities that exist in the everyday actions that occur within a variety of organisations and places.

It is interesting to contrast the relational activism promoting ethical consumption within FTTs and the conventional understanding of the role traditional activism plays in stimulating more ethical consumption and production. The dominant framing concentrates on activist efforts via communication to recruit consumers and "discipline" institutions (Sandlin and Callahan 2009). Gopaldas (2014), in his exploration of how "marketplace sentiments" can be harnessed to create change within markets, characterises activism as conducted by non-profit organisations who engage in "delivering provocative, emotionally charged, and even polarizing rhetoric, imagery, and protests whenever they can seize moments of media coverage and consumer attention" (p. 1000). He emphasises that:

Successful activist groups recognize that their communications must be 'extraordinary' to capture consumer attention... activists vividly express sentiments in the 'contempt for villains' and 'care for victims' categories. However, activists seem to make fewer efforts to cultivate sentiments in the 'celebration of heroes' category. In particular, the joy of making responsible choices is less salient in activist expressions, especially in contrast to brand expressions.

By contrast, the role of FTT activists involves a range of activities beyond communication, and the communication they do engage in is far more "everyday" rather than "extraordinary". Although they do communicate that conventional supply chain arrangements can create victims within poorer countries, the emphasis is much more on celebrating the role of alternative trading systems, the positive benefits they have on peoples' lives, and the role of the community and consumer as a force for positive change. This is communicated through initiatives such as organising producer visits during Fairtrade Fortnight in which FT producers can meet the people within FTTs and communicate the benefits of FT through attending events, addressing schools and through local media coverage. The contrast that emerges from the findings of this research, between FTT activism and the dominant understanding of conventional forms of market-related activism, is summarised in Table 3.

Another potential role that FTTs play is an integrative one between types of marketplace activism, including different conceptions of FT. Wilkinson (2007) argues that considerable tension exists between those in the FT movement who seek to promote mainstreaming in existing markets, and thereby engage with the objectives of corporate social responsibility and ethical trade, and those who see themselves as part of the solidarity economy movement and seek to provide opportunities for disenfranchised producers in markets like handicrafts. FTTs, with their ability to engage directly both with producers and producer communities, and with retailers from the mainstream/international to the alternative/local, integrate these two elements of the movement through their activities. This perhaps represents an additional dimension of the evolution of FT, through FTT, to a place-based phase (Alexander and Nicholls 2006) in terms of the evolving role of activism. The activism that built the FT movement, described by Hira and Ferrie (2006), can be viewed as generally international and strategic in its focus. The activism evident within FTTs is more locally focused (albeit with the aim of creating change in global trading systems) and concerned more with operational/practical marketing issues linked to distribution and promotion. Arguably, one consequence of mainstreaming has been to take the strategic market development role away from the activist community, as large corporate players in retailing and production have become more involved (framed by the likes of Child (2015) as the capture of the movement by corporate interests). The emergence of a thriving international FTT scene has produced a new and valuable arena for activist contributions to the FT movement.

There is an argument that the conventional framing of marketplace activists represents a misnomer. Such stakeholders typically seek to change the marketplace actions of others (particularly consumers, investors and institutions such as manufacturers) through communications strategies that motivate others to change their behaviours (Gopaldas 2014; Hendry 2005; Sandlin and Callahan 2009). Although these stakeholders may engage in direct action, this is typically political action aimed at generating media attention for marketplace behaviours, dynamics and consequences. At its heart, this is about marketplace advocacy more than action. Indeed Wilkinson (2007) notes that Oxfam, a key actor in bringing the concept of FT to the market, has now withdrawn from its trading role to concentrate on advocacy. This he sees as symptomatic of FT institutions having to choose between an advocacy and marketplace development focus. FTT activists, by contrast, seek to engage in their local marketplaces more directly through a combination of advocacy and action. There is an element of communications focused work, but there is also attention paid to the practicalities of product distribution, to getting local retailers to stock FT and monitoring the extent to which they are doing so, to encouraging local 
Table 3 Conventional versus FTT activism comparison

\begin{tabular}{|c|c|}
\hline Conventional campaign activism & FTT relational activism \\
\hline Led by SMOs at a national-level (Hendry 2005) & Led by self-organising grassroots groups at a local level \\
\hline $\begin{array}{l}\text { Sometimes based on partnerships, but more usually involving confrontational } \\
\text { relationships with SMOs seeking to "discipline" firms (Sandlin and Callahan } \\
\text { 2009) }\end{array}$ & $\begin{array}{l}\text { Based on a network of relationships with local-to-global } \\
\text { market stakeholders }\end{array}$ \\
\hline $\begin{array}{l}\text { Typically seeks to deter retailers from stocking and consumers/organisations } \\
\text { buying products seen as unethical via boycotts (Sandlin and Callahan 2009) }\end{array}$ & $\begin{array}{l}\text { Encourages retailers to stock and consumers/organisations to } \\
\text { "buycott" ethical FT products }\end{array}$ \\
\hline Relies on "extraordinary" communications (Gopaldas 2014) & $\begin{array}{l}\text { Relies on everyday conversations, events and opportunities to } \\
\text { communicate }\end{array}$ \\
\hline Focuses on "contempt for villains" (Gopaldas 2014) & $\begin{array}{l}\text { Focuses on "care for victims" and "celebration of heroes" } \\
\text { (Gopaldas 2014) }\end{array}$ \\
\hline $\begin{array}{l}\text { Seeks to involve political consumers on ethical grounds through advocacy } \\
\text { (Wilkinson 2007) }\end{array}$ & $\begin{array}{l}\text { Also seeks to involve consumers from a local solidarity } \\
\text { perspective and through acts of exemplary consumption }\end{array}$ \\
\hline $\begin{array}{l}\text { Influence exerted through resource dependent relationships and determined by } \\
\text { relative power (Hendry 2005) }\end{array}$ & $\begin{array}{l}\text { Influence exerted through leveraging social capital and social } \\
\text { networks }\end{array}$ \\
\hline $\begin{array}{l}\text { Increasingly enacted through online communities (Hollenbeck and Zinkhan } \\
\text { 2006) }\end{array}$ & $\begin{array}{l}\text { Enacted through local geographical communities and face-to- } \\
\text { face interactions }\end{array}$ \\
\hline
\end{tabular}

organisations to consume FT or local consumers to sample it, and to weaving FT into everyday aspects of towns including events, tourism strategies, town guides and websites, classroom activities, signage and even floral displays. Through their emphasis on building relationships and networks, there is also considerable attention paid to connecting organisations and establishing activities and events that bring people together. It is an altogether more action-orientated form of activism.

\section{Conclusions}

The research presented here, like any other, has limitations. By focusing on the role of the activist in the FTT marketing system, it potentially understates the role that other key stakeholders play. Further studies considering other stakeholders' contributions within FTTs could advance our understanding of their operation as a total marketing system (Layton 2007). For example, insights from the Fairtrade Foundation, Local Authorities, FTT residents, other community groups and FT producers who have visited FTTs as part of a promotional tour, would unquestionably advance this work. In addition, general consumer insight (geographically bound specifically to FTTs) could also help to reveal the impact of the activist strategies and roles discussed within this paper. Similarly, the focus here is on the impact that the activists have on the marketing dynamics of FTTs, rather than on understanding their role within FT as a social movement, or on understanding the steering groups themselves as organisations in terms of their motivation, composition and political dynamics. Such issues represent potentially interesting avenues for future research. Another limitation arises from the sampling method used, whereby the use of recommendations from one group to talk to another inevitably led to groups being recommended on the basis of being active, innovative or successful. This potentially skewed the research away from groups that have struggled to succeed, and therefore limits the insight gained into the challenges that FTT activist groups can face and how they can overcome them. Finally, as identified by Lyon (2014), the rapid mainstreaming that has witnessed global brands such as Starbucks, Cadbury, Nestlé and Tate \& Lyle adopting the FT label, potentially places FTT activists at a crossroads regarding their role and their perception of it, and raises questions about what they should or can do next. These are important issues emerging for FTT activists, but were not themes that this research sought to explore.

From their UK origins, FTTs have grown to represent an increasingly global, and globalising, ethical marketing phenomenon with the potential to influence markets and the fabric of life within consumer communities, and lives within producer communities. This paper contributes to our understanding of FTTs, and the role of the activists within them, from an ethical marketing perspective in several ways:

- By extending our understanding of how FTTs operate, both as a marketing network, as identified by Nicholls and Opal (2005), and as a form of activist-motivated marketing initiative. Hira and Ferrie (2006) argue that a key to further expanding FT markets lies in developing local solutions to the challenges that FT marketers face 
linked to issues of accreditation, channel management and increasing awareness, availability and credibility. What this paper contributes is further insight into how local activists are meeting these challenges and fulfilling the key activist roles that Hira and Ferrie (2006) identify, including guardian of certification systems, market innovator, advocate for (local) government support, promoter of FT as a form of standard, and proponent of accountability and responsiveness amongst system stakeholders. This understanding of FTTs' marketing role helps to bridge the gap between Lyon's (2014) exploration of how FTTs operate from a political perspective as one agenda-driven entity amongst many within local economies, and Wheeler's (2012) assessment of FTTs' ability to engage citizenconsumers in ethical practices.

- By illustrating the multi-faceted role played by local FTT activists as informal marketers, who lack the commercial marketers' formal responsibility for managing the production/consumption interface through marketing mix management, branding and retailing, yet seek to enhance that interface's reach and effectiveness in several ways. Although previous research has suggested that steering group activists are a success factor for FTTs, how they contribute to that success has not previously been explored. The picture that emerges here is one of the activists exerting multi-level marketing system influence, from engaging family and friends through social ties and exemplary consumption, to pressurising local institutions and outlets of international retail chains. So although authors like Nicholls (2010) see the success of FT as driven by a coalition of marketers and activists, at the level of the FTT success comes from the activists adopting roles as marketers (Lyon 2014).

- By demonstrating that FTTs represent an atypical form of market activism, as summarised in Table 3, and also that as a form of community activism they are atypical in two particular ways. Firstly, the social cause around which local activism is mobilised does not relate to events, circumstances, problems or specific racial or religious groups within that community (as would be the case for community protests against a company reflecting local impacts from pollution, noise or traffic congestion for example). FTT activism is not even considering a cause within the immediate society that the community is a part of (although there is growing FT consumption within developing countries, as shown by several examples in Raynolds et al. (2007)). FTT activists may pursue global goals, but they do this through local means and by using local knowledge, identities and connections. Their work resembles political activism, whereby activities like canvassing, leafleting and rallies represent local manifestations of a national movement. Secondly, although there is some traditional activism in directly influencing consumers and retailers, much of their effort is invested in the under-researched (O'Shaughnessy and Kennedy 2010) aspect of relational activism by drawing a range of local organisations and influential stakeholders into a complex network of pressure and support. As O'Shaughnessy and Kennedy (2010, p. 553) note “....relational activism is a long-term form of activism that utilizes relationships among networks of likeminded individuals, and blurs the distinction between public and private-spheres by using daily behaviours as the locus for social and environmental change". This blurring of public and private sphere boundaries extends in FTTs to marketing efforts that simultaneously address consumer markets, organisational/public sector markets and social enterprises. These two facets of a relational, rather than confrontational, focus and a globally inspired/locally enacted activism are combined in FTT activist efforts to build relationships between consumer and producer communities, and in doing so promote a production-consumption system understanding of FT amongst local citizens.

- By highlighting the broad strategies and key tactics used by FTT activists seeking to both stimulate local market demand, and build local market capacity. These reveal FTTs as a pragmatic form of activism that goes beyond merely using communication techniques to encourage end consumers or producers to change their behaviours. The emphasis on leveraging the social networks and relationships that exist within a community reveals a form of relationship marketing based on personal relationships and face-to-face interactions. This is in marked contrast to other forms of ethical (and/or anti-conventional capitalism) activism campaigns that are increasingly making use of the internet and other communication technologies to mobilise and exert pressure (Hollenbeck and Zinkhan 2006; Sandlin and Callahan 2009). However, greater online influence was seen as a future direction for FTTs and their quest to involve more young activists was seen as a gateway leading in that direction.

- By contributing to our understanding of how local stakeholders and processes can support the development of ethical markets from a macromarketing perspective. Although there are examples of localised macromarketing studies, and Layton and Grossbart's (2006) review of the field note several, they remain few compared to studies of national markets or industry systems.

- By revealing FTTs development not just as a new place-based phase in FT market development 
(Alexander and Nicholls 2006) but also as a further evolution and extension of the activism that has sparked and shaped the FT movement (Hira and Ferrie 2006).

The insights generated here into the success of FTT activism and how it operates, could have relevance for understanding and promoting other locally orientated ethical consumption initiatives such as slow consumption, local exchange trading or currency schemes, or community enterprises seeking to address key social and environmental needs. The success of FTT activists is grounded in their ability to exert multi-level, multi-stakeholder influence by leveraging their own social capital and networks, and integrate their efforts into a "local ecology" of ethical causes, networks and institutions, to communicate a globally inspired ethical case with local resonance. The marketing dynamics and activists roles revealed within FTTs opens up a range of research opportunities exploring the informal marketer role that activists adopt, the relational style of activism they pursue and the market-building strategies and tactics they adopt. As the FTT movement grows in its international scope, the lessons drawn from studying UK FTTs may aid our understanding of the processes involved and the potential to apply them to further develop FT and other forms of ethical markets.

Open Access This article is distributed under the terms of the Creative Commons Attribution 4.0 International License (http://creative commons.org/licenses/by/4.0/), which permits unrestricted use, distribution, and reproduction in any medium, provided you give appropriate credit to the original author(s) and the source, provide a link to the Creative Commons license, and indicate if changes were made.

\section{References}

Alexander, A., \& Nicholls, A. (2006). Rediscovering consumerproducer involvement: A network perspective on fair trade marketing. European Journal of Marketing, 40(11/12), $1236-1253$.

Amin, A. (2002). Spatialities of globalisation. Environment and Planning, 34(3), 385-399.

Around, E. (2006). The Fairtrade Towns Initiative: Lessons from across the Ocean. Boston: Oxfam America.

Barnett, C., Cloke, P., Clarke, N., \& Malpass, A. (2011). Globalizing responsibility: The political rationalities of ethical consumption. Chichester: Wiley-Blackwell.

Blaikie, N. (2000). Designing social research. Cambridge: Polity Press.

Brown, K. R. (2011). Interaction ritual chains and the mobilization of conscientious consumers. Qualitative Sociology, 34(1), 121-141.

Bryant, R., \& Goodman, M. (2004). Consuming narratives: The political ecology of 'alternative' consumption. Transactions of the Institute of British Geographers, 29, 344-366.

Carmarthenshire Sustainability. (2011). Retrieved 07 May, 2011 from http://www.sirgaerfyrddin.gov.uk/english/environment/sustain ability/pages/makingcarmarthenshireasustainablecounty.aspx.

Castaldo, S., Perrini, F., Misani, N., \& Tencati, A. (2009). The missing link between corporate social responsibility and consumer trust: The case of fair trade products. Journal of Business Ethics, 84(1), 1-15.

Chatzidakis, A., Hibbert, S., \& Smith, A. P. (2007). Why people don't take their concerns about fair trade to the supermarket: The role of neutralisation. Journal of Business Ethics, 74(1), 89-100.

Chatzidakis, A., Kastanakis, M., \& Stathopoulou, A. (2016). Sociocognitive determinants of consumers' support for the fair trade movement. Journal of Business Ethics, 133(1), 95-109.

Child, C. (2015). Mainstreaming and its discontents: Fair trade, socially responsible investing, and industry trajectories. Journal of Business Ethics, 130(3), 601-618.

Clarke, N., Barnett, C., Cloke, P., \& Malpass, A. (2007). The political rationalities of fair-trade consumption in the United Kingdom. Politics \& Society, 35(4), 583-607.

Davies, I. A. (2009). Alliances and networks: Creating success in the UK fair trade market. Journal of Business Ethics, 86(1), 109-126.

Davies, I. A., \& Crane, A. (2003). Ethical decision making in fair trade companies. Journal of Business Ethics, 45(1-2), 79-92.

Davies, I. A., Doherty, B., \& Knox, S. (2010). The rise and stall of a fair trade pioneer: The Cafédirect story. Journal of Business Ethics, 92(1), 127-147.

Davies, I. A., \& Ryals, L. J. (2010). The role of social capital in the success of fair trade. Journal of Business Ethics, 96(2), 317-338.

De Pelsmacker, P., \& Janssens, W. (2007). A model for fair trade buying behaviour: The role of perceived quantity and quality of information and of product-specific attitudes. Journal of Business Ethics, 75(4), 361-380.

den Hond, F., \& de Bakker, F. G. A. (2007). Ideologically motivated activism: How activist groups influence corporate social change activities. Academy of Management Review, 32(3), 901-924.

Denzin, N. K. (1989). Interpretive interactionism. Newbury Park, CA: Sage.

Doherty, B., Davies, I. A., \& Tranchell, S. (2013). Where now for fair trade? Business History, 55(2), 161-189.

Doran, C. J. (2009). The role of personal values in fair trade consumption. Journal of Business Ethics, 84(4), 549-563.

Doran, C. J., \& Natale, S. M. (2011). Empatheia and carita: The role of religion in fair trade consumption. Journal of Business Ethics, 98(1), 1-15.

Dubuisson-Quellier, S., \& Lamine, C. (2008). Consumer involvement in fair trade and local food systems: Delegation and empowerment regimes. GeoJournal, 73(1), 55-65.

Fairtrade Annual Report. (2016). Retrieved 25 September, 2016 from https://annualreport15-16.fairtrade.net/en/.

Fairtrade Foundation. (2016). Retrieved 20 June, 2016 from http:// www.fairtradetowns.org/resources/goals-action-guides.

Fairtrade Impact Story. (2016) Retrieved 25 September, 2016 from http://ourimpactstory.fairtrade.org.uk/a-journey-we-are-walkingtogether/.

Fairtradetowns.org. (2016). Retrieved 01 January, 2016 from http:// www.fairtradetowns.org/.

Geiger-Oneto, S., \& Arnould, E. J. (2011). Alternative trade organization and subjective quality of life: The case of Latin American coffee producers. Journal of Macromarketing, 31(3), 276-290.

Glaser, B. G., \& Strauss, A. (1967). The discovery of grounded theory: Strategies for qualitative research. Piscataway, NY: Aldine Transaction.

Golding, K. M., \& Peattie, K. (2005). In search of a golden blend: Perspectives on the marketing of fair trade coffee. Sustainable Development, 13, 154-165.

Gopaldas, A. (2014). Marketplace sentiments. Journal of Consumer Research, 41(4), 995-1014.

Goulding, C. (1998). Grounded theory: The missing methodology on the interpretivist agenda. Qualitative Marketing Research: An International Journal, 1(1), 50-57. 
Granovetter, M. S. (1973). The strength of weak ties. American Journal of Sociology, 78, 1360-1380.

Guay, T., Doh, J. P., \& Sinclair, G. (2004). Non-governmental organizations, shareholder activism, and socially responsible investments: Ethical, strategic, and governance implications. Journal of Business Ethics, 52(1), 125-139.

Hendry, J. R. (2005). Stakeholder influence strategies: An empirical exploration. Journal of Business Ethics, 61(1), 79-99.

Hira, A., \& Ferrie, A. (2006). Fair trade: Three key challenges for reaching the mainstream. Journal of Business Ethics, 63(2), 107-118.

Hoffmann, S., \& Hutter, K. (2012). Carrotmob as a new form of ethical consumption. The nature of the concept and avenues for future research. Journal of Consumer Policy, 35(2), 215-236.

Hollenbeck, C. R., \& Zinkhan, G. M. (2006). Consumer activism on the internet: The role of anti-brand communities. Advances in Consumer Research, 33(1), 479-485.

Hutchens, A. (2009). Changing big business: The globalisation of the fair trade movement. Cheltenham: Edward Elgar.

Jaffee, D. (2007). Brewing justice fair trade coffee, sustainability, and survival. London: University of California Press.

Jaffee, D. (2010). Fair trade standards, corporate participation, and social movement responses in the United States. Journal of Business Ethics, 92(2), 267-285.

Kim, G. S., Lee, G. Y., \& Park, K. (2010). A cross-national investigation on how ethical consumers build loyalty toward fair trade brands. Journal of Business Ethics, 96(4), 589-611.

Klar, M., \& Kasser, T. (2009). Some benefits of being an activist: Measuring activism and its role in psychological well-being. Political Psychology, 30(5), 755-777.

Kourala, A., \& Laasonen, S. (2010). Nongovernmental organizations in business and society, management and international business literature: Review and implications, 1998-2007. Business and Society, 49(1), 35-67.

Kozinets, R. V., \& Handelman, J. M. (2004). Adversaries of consumption: Consumer movements, activism, and ideology. Journal of Consumer Research, 31(3), 691-704.

Lang, T., \& Gabriel, Y. (2005). A brief history of consumer activism. In R. Harrison, T. Newholm, \& D. Shaw (Eds.), The ethical consumer. London: Sage.

Layton, R. A. (2007). Marketing systems-A core macromarketing concept. Journal of Macromarketing, 23(3), 227-242.

Layton, R. A., \& Grossbart, S. (2006). Macromarketing: Past present and possible future. Journal of Macromarketing, 26(2), 193-213.

Lyon, S. (2014). Fair trade towns USA: Growing the market with a diverse economy. Journal of Political Ecology, 21, 145-160.

Malpass, A., Cloke, P., Barnett, C., \& Clarke, N. (2007). Fairtrade urbanism? The politics of place beyond place in the Bristol Fairtrade City campaign. International Journal of Urban and Regional Research, 31(3), 633-645.

Martin, D. G., Hanson, S., \& Fontaine, D. (2007). What counts as activism? The role of individuals in creating change. Women's Studies Quarterly, 35(3/4), 78-94.

Micheletti, M. (2003). Political virtue and shopping: Individuals, consumerism and collective action. London: Palgrave.
Miles, M., \& Huberman, A. M. (1994). Qualitative data analysis. Thousand Oaks, CA: Sage.

Moore, G. (2004). The fair trade movement: Parameters, issues and future research. Journal of Business Ethics, 53(1/2), 73-86.

Nicholls, A. (2010). Fair trade: Towards an economics of virtue. Journal of Business Ethics, 92(2), 241-255.

Nicholls, A., \& Opal, C. (2005). Fair trade market driven ethical consumption. London: Sage.

O'Shaughnessy, S., \& Kennedy, E. H. (2010). Relational activism: Re-imagining women's environmental work as cultural change. Canadian Journal of Sociology, 35(4), 551-572.

Paynton, S. T., \& Schnurer, M. (2010). Corporate "grassroots" activism. Business and Professional Ethics Journal, 29(1/4), 63-83.

Raynolds, L. T., Murray, D., \& Wilkinson, J. (2007). Fair trade: The challenges of transforming globalization. Abington, Oxon: Routledge.

Samuel, A., \& Peattie, K. (2015). Grounded theory as a macromarketing methodology critical insights from researching the marketing dynamics of fairtrade towns. Journal of Macromarketing, 36(1), 11-26.

Sandlin, J. A., \& Callahan, J. L. (2009). Deviance, dissonance, and détournement culture: Jammers use of emotion in consumer resistance. Journal of Consumer Culture, 9(1), 79-115.

Seguin, C., Pelletier, L. G., \& Hunsley, J. (1998). Toward a model of environmental activism. Environment and Behavior, 30(5), $628-652$.

Seyfang, G. (2005). Shopping for sustainability: Can sustainable consumption promote ecological citizenship? Environmental Politics, 14(2), 290-306.

Seyfang, G., \& Haxeltine, A. (2011). Growing grassroots innovations: Exploring the role of community-based initiatives in governing sustainable energy transition. Environment and Planning, 4(30), 381-400.

Shaw, D., Newholm, T., \& Dickinson, R. (2006). Consumption as voting: An exploration of consumer empowerment. European Journal of Marketing, 40(9/10), 1049-1067.

Shreck, A. (2005). Resistance, redistribution, and power in the Fair Trade banana initiative. Agriculture and Human Values, 22(1), 17-29.

Smith, A. M. (2009). Evaluating the criticisms of fair trade. Economic Affairs, 29(4), 29-36.

Smith, N. C. (1990). Morality and the market: Consumer pressure for corporate accountability. London: Routledge.

Strauss, A., \& Corbin, J. (1998). Basics of qualitative research techniques and procedures for developing grounded theory (2nd ed.). London: Sage.

Tallontire, A. (2001). Challenges facing fair trade: Which way now? DSA conference. Different Poverties, Different Policies. IDMP. Manchester 10-12 September 2001.

Wheeler, K. (2012). The practice of fairtrade support. Sociology, 46(1), 126-141.

Wilkinson, J. (2007). Fair trade: Dynamic and dilemmas of a market oriented global social movement. Journal of Consumer Policy, 30(3), 219-239. 